\title{
Persepsi Wisatawan Eropa Terhadap Paket Wisata Pedesaan (Rural Activity) Pada D'karang Homestay, Bali
}

\author{
Ni Putu Evi Wijayanti
}

Program Studi Manajemen Bisnis Perjalanan, Politeknik Pariwisata Bali

Email: putueviwijayanti@gmail.com

\begin{abstract}
Received: Mei, 2020
Accepted: Mei, 2020

Published: June, 2020

Abstract

Rural tourism is one tour package that is highly desirable for foreign tourists, especially European tourists. Rural tourism has an important role and provides many benefits in tourism sector for rural communities. When tourists travel to rural areas, they indirectly help local communities in developing rural areas and living standards. Furthermore, homestay is one of the criteria for a tourist village. Homestay is a product of the tourism industry where tourists can meet directly with local residents. Tourists who stay at the homestay and given an offer of rural tour packages, can be an opportunity for the community to attract tourists to stay longer by enjoying a variety of natural and cultural activities in the tourist village. This study aimed to determine the perceptions of European tourists on rural tour packages at D'Karang Homestay. The benefit of this research is to add references in tourism studies especially about the perceptions of European tourists on rural tourism packages. The research methods used were observation, interview, questionnaire and documentation. This research revealed European tourist perceptions of the rural tour packages offered by D'Karang Homestay but there are still shortcomings that need to be corrected.
\end{abstract}

Keywords: European travelers, rural travel packages, homestay

\begin{abstract}
Abstrak
Rural tourism merupakan salah satu paket wisata yang sangat diinginkan oleh wisatawan mancanegara khususnya wisatawan Eropa. Pariwisata pedesaan (Rural Tourism) adalah bentuk penting dari sektor pariwisata yang memainkan peran penting dan memberikan banyak manfaat bagi masyarakat pedesaan. Ketika wisatawan berpergian ke daerah pedesaan, mereka secara tidak lansung membantu dalam pengembangan daerah pedesaan dan standar hidup masyarakat lokal. Homestay merupakan salah satu kriteria dari adanya desa wisata. Homestay merupakan salah satu produk dari industri pariwisata dimana wisatawan dapat bertemu langsung dengan warga setempat. Penawaran paket wisata pedesaan (Rural Activity) bagi wisatawan yang tinggal di homestay dapat menjadi peluang bagi masyarakat untuk menarik wisatawan tinggal lebih lama untuk menikmati beragam aktivitas alam dan budaya di Desa wisata. Tujuan penelitian ini adalah untuk mengetahui persepsi wisatawan Eropa terhadap paket wisata pedesaan (Rural Activity) di D'Karang Homestay. Manfaat penelitian ini adalah untuk menambah referensi dalam kajian pariwisata khususnya tentang persepsi wisatawan Eropa terhadap paket wisata pedesaan. Metode penelitian yang digunakan adalah observasi, wawancara, kuesioner dan dokumentasi. Penelitian ini menggungkap persepsi wisatawan Eropa terhadap paket wisata pedesaan yang ditawarkan oleh D'karang Homestay tetapi masih ada kekurangan yang perlu diperbaiki.
\end{abstract}

Kata kunci: wisatawan Eropa, paket wisata pedesaan, homestay. 


\section{PENDAHULUAN}

Tren pariwisata saat ini mengalami perubahan seperti adanya pergeseran minat wisatawan dalam membeli produk wisata, dimana sebelumnya adalah "buying product" menjadi "buying experience'. Wisata pedesaan dipandang sebagai salah satu cara yang menyenangkan untuk melatihan diri menuju kehidupan dan kesehatan yang lebih baik di antara banyak orang. Menikmati makanan otentik suatu pedesaan juga menjadi populer di kalangan wisatawan Eropa.

Bali sebagai daerah tujuan wisata telah didukung dengan adanya peningkatan fasilitas yang menunjang seperti : hotel,villa, biro perjalanan wisata, industri transportasi, daya tarik wisata serta dilihat juga dengan adanya kunjungan wisatawan ke Bali baik manacanegara maupun domestic mengalami peningkatan dari tahun ke tahun selama 5 tahun pada tahun 2015 ke tahun 2016 mengalami pertumbuhan hingga 22,55 persen.Dengan semakin meningkatnya jumlah kunjungan wisatawaan yang datang ke Bali menyebabkan pemerintah daerah Bali semakin gencar untuk memperbaiki segala sektor yang berkaitan dengan keberlangsungan pariwisata Bali. Salah satu kabupaten yang ada di Bali yang sedang gencar - gencarnya membangun pariwisata adalah Kabupaten Bangli.

Kabupaten Bangli menjadi salah satu tempat tujuan wisata yang banyak dikunjungi wisatawan domestik maupun mancanegara setiap tahunnya. Pemerintah daerah Kabupaten Bangli telah menetapkan 22 desa sebagai desa wisata. Selanjutnya disesuaikan melalui Keputas Dirjen Pengembangan Destinasi Pariwisata No.29/KEP/DPDP/I/- 2013 tentang Tata Cara Penyaluran PNMP (Program Nasional Pemberdayaan Masyarakat) Mandiri Pariwisata 2013 dan Program Bali MandaraNo.556/317/I/DISPAR tentang Pengembangan 22 Desa Wisata. Seluruh desa wisata tersebut tersebar di 4 Kecamatan yang ada di Kabupaten Bangli yaitu Kecamatan Bangli, Susut, Tembuku dan Kintamani. Berdasarkan hasil observasi awal rata - rata kegiatan yang ditawarkan di desa wisata bernuansa pedesaan, seperti kegiatan treaking di persawahan, cycling, cooking leason dan mereka biasanya tinggal di homestay, sehingga kegiatan tersebut dimasukan dalam katagori "Rural Activity"atau wisata pedesaan.

Salah satu desa wisata yang mengembangkan kegiatan pedesaan atau Rural Activity adalah Desa Wisata Undisan. Lokasinya di Kecamatan Tembuku dengan luas wilayah 300 km2. Suasana Desa Wisata Undisan sangatlah menarik seperti Desa Penglipuran yang dikenal sebagai desa yang indah, menarik dan terbersih di dunia bersanding dengan Desa Giethoorn di Belanda dan Desa Mawlynnong di India. Suasana alam desa Undisana masih begitu asri, udara sejuk dan budaya lokal yang begitu kental. Para pengunjung dengan bebas dapat menikmati suasana alam di sekitar desa. Pengunjung dapat melakukan aktivitas yang menarik seperti trakking, bersepeda, membajak sawah dengan sapi, mengikuti cooking class, dan kegiatan lainnya. Desa Undisan juga terdapat kerajinan emas dan perak. Salah satu objek wisata yang mengagumkan adalah Air Terjun Tangkup. Di desa ini juga terdapat penginapan, hotel hingga bungalow sebagai akomodasi untuk pengunjung. Salah satu akomodasi yang menarik untuk dikunjungi adalah D'Karang Homestay yang terletak di Banjar Lokasari, Desa Undisan Kelod, Tembuku, Bangli. Arsitektur bangunan dan suasana pekarangan yang indah khas Bali merupakan hal menarik yang dimiliki oleh D'Karang Homestay. D'Karang Homestay berarti 'Pekarangan', yang menonjolkan arsitektur khas Bali menawan serta indah. Kegiatan yang bisa dilakukan untuk pengunjung di tempat ini antara lain; treking ke air terjun sambil mempelajari tanaman obat-obatan, membuat jamu tradisional, pelajaran memasak makanan khas Bali, eco-cycling, pelajaran menari Bali, menangkap bebek, membajak sawah dengan sapi hingga menanam padi di sawah. D'Karang Homestay menyediakan tujuh kamar dengan fasilitas yang unik. Wisatawan banyak berminat untuk menginap di D’Karang homestay, khususnya wisatawan Eropa.

Berdasarkan paparan tersebut penting untuk melakukan penelitian terhadap persepsi wisatawan Eropa terhadap paket wisata pedesaan (Rural Activity) di D’Karang Homestay, 
Desa wisata Undisan, Bangli. Penelitian ini bertujuan untuk mengetahui apa persepsi wisatawan Eropa terhadap paket wisata pedesaan (rural Activity) di D'karang homestay serta mengetahui seberapa besar dampak paket wisata pedesaan ini terhadap lama tinggal wisatawan di D'karang homestay. Penelitian ini diharapkan dapat bermanfaat untuk menambah wawasan dan pengetahuan pembaca tentang paket wisata pedesaan /rural tourism khususnya yang ditawarkan di homestay di Kabupaten Bangli dan sebagai referensi bagi peneliti dalam menyusun penelitian lanjutan maupun penelitian dengan topik yang sama.

\section{METODE PENELITIAN}

Penelitian ini dilakukan di Desa Wisata Undisan, Kecamatan Tembuku, Kabupaten Bangli, Bali 80671. Nomber telephone: (08124610261). Penelitian ini menggunakan data kualitatif dan data kuantitatif. Data kualitatif yang digunakan dalam penelitian ini adalah deskripsi tentang gambaran umum objek penelitian. Selain itu data hasil penyebaran kuesioner yang digunakan adalah data hasil wawancara dengan pihak - pihak terkait dengan pelaksanaan kegiatan wisata pedesaan di D'karang homestay, Kecamatan Bangli, Kabupaten Bangli. Data kuantitatif dalam penelitian ini berupa kunjungan wisatawan ke Propinsi Bali dan Kabupaten Bangli serta data hasil penyebaran kuesioner yang digunakan untuk mengetahui persepsi wisatawan Eropa terhadap paket wisata pedesaan/rural activity pada D'karang Homestay di Kabupaten Bangli. Sumber data berasal dari data primer, didapat dari hasil observasi tentang kondisi fisik lokasi kegiatan atraksi wisata pedesaan seperti rute trekking, cycling, dan cooking lesson, hasil pengisian kuesioner dan hasil wawancara dari wisatawan Eropa dan pihak - pihak terkait dengan atraksi wisata pedesaan. Data sekunder berupa data atau arsip mengenai kependudukan yang dimiliki Desa Wisata Undisan, Data jumlah kunjungan wisata dari Dinas Pariwisata Provinsi Bali dan Kabupaten Bangli. Data tersebut bisa berupa jurnal, buku referensi, catatan - catatan penunjang, buku perpustakaan, dokumentasi dan keterangan-keterangan yang berhubungan dengan masalah penelitian yang digunakan sebagai pelengkap dan pendukung dari data primer.

Dalam penelitian ini yang menjadi populasi adalah wisatawan Eropa yang membeli dan mengikuti kegiatan atraksi wisata pedesaan / rural activity pada D'Karang Homestay, Desa Undisan, Kecamatan Tembuku, Kabupaten Bangli dari tahun 2015-2018. Sampelnya yaitu dengan menyebarkan kuesioner dan beberapa wawancara ke wisatawan Eropa yang sudah membeli dan mengikuti kegiatan atraksi wisata pedesaan pada D'Karang Homestay, Desa Wisata Undisan, Kecamatan Tembuku, Kabupaten Bangli.

Teknik pengumpulan data dengan cara observasi, wawancara, kuesioner, dan studi dokumentasi. Hasil observasi yang dilakukan kepada wisatawan Eropa yang melakukan kegiatan wisata pedesaan / rural tourism pada D'karang Homestay pada saat penyebaran kuisioner. Wawancara yang akan dilakukan nanti adalah dengan wawancara tidak terstruktur, wawancara yang bebas dimana peneliti tidak menggunakan pedomanpedoman wawancara yang telah tersusun secara sistematis dan lengkap untuk pengumpulan datanya (Sugiyono,2008:140). Kuisioner digunakan untuk memperoleh data persepsi wisatawan yang telah membeli dan melakukan kegiatan wisata pedesaan/ rural activity pada D'karang Homestay, Desa Wisata Undisan, Kecamatan Tembuku, Kabupaten Bangli. Dokumen yang diperoleh dapat berupa, buku-buku penunjang kajian teori, foto foto dan artikel - artikel yang terkait baik dalam media cetak, maupun internet.

Teknik analisis data dalam penelitian ini adalah upaya mengolah data menjadi informasi, sehingga karakteristik atau sifat - sifat data tersebut dapat dengan mudah dipahami dan bermanfaat untuk menjawab masalah - masalah yang berkaitan dengan kegiatan penelitian. Teknik analisis data kuantitatif, yaitu lebih berdasarkan pada analisis data yang dapat dihitung untuk menghasilkan penaksiran kuantitatif yang kokoh (Umar Husein,2003;37). Teknik ini digunakan dalam penentuan penyajian data melalui tabel, 
grafik perhitungan presentasi dari hasil wawancara, daftar pertanyaan/kuesioner yang telah disebarkan di lapangan. Untuk parameter nilai dari pendapat pada responden penelitian ini menggunakan skala likert untuk menunjukkan sikap seseorang terhadap sesuatu dari keadaan yang sangat positif sampai keadaan yang sangat negatif berkenaan persepsi wisatawan Eropa yang mengikuti kegiatan wisata pedesaan/ rural activity pada D’karang Homestay. Responden diberikan 5 alternatif jawaban, rentang skala yang digunakan adalah 1 sampai 5 dengan pemetaan bobot sebagai berikut (Durianto dkk,2001;4)

Skala 1 = Sangat Kurang, diberi bobot 1

Skala $2=$ Kurang, diberi bobot 2

Skala 3 = Cukup, diberi bobot 3

Skala 4 = Baik, diberi bobot 4

Skala 5 = Sangat Baik, diberi bobot 5

Selanjutnya data yang telah diperoleh kemudian dihitung dengan menggunakan rumus nilai rata- rata untuk mengetahui nilai rata- rata dari setiap aspek yang dimiliki. Dari nilai tersebut kita dapat mengetahui bagaimana persepsi wisatawan Eropa terhadap paket wisata pedesaan/ rural activity pada D'karang Homesty. Adapu rumus yang digunakan adalah :

Dimana:

$$
\begin{array}{ll}
\mathrm{X} & =\text { nilai rata-rata } \\
\mathrm{B} & =\text { bobot nilai } \\
\mathrm{n} & =\text { jumlah responden } \mathrm{N}=\text { total responden }
\end{array}
$$

Hasil dari nilai rata-rata kemudian dipetakan ke rentang skala yang mempertimbangkan informasi interval berikut ini:

Interval=(nilai tertinggi-nilai terendah $) /($ banyaknya kelas $)=(5-1) / 5=0.80$

Berdasarkan hasil indeks kumulatif terhadap atribut penelitian tersebut akan disesuaikan dengan rentang skala kriteria penilaian indeks sikap konsumen dengan tujuan untuk mengetahui persepsi wisatawan Eropa terhadap paket wisata pedesaan / rural activity pada D’karang Homestay, Kecamatan Tembuku, Kabupaten Bangli. Rentang skala kriteria kepuasan indeks sikap konsumen adalah sebagai berikut:

1.00-1.80 = Sangat Tidak Puas

$1.81-2.60=$ Tidak Puas

2.61-3.40 = Cukup Puas

$3.41-4.20=$ Puas

4.21-5.00 = Sangat Puas

Adapun tahapan-tahapan dalam analisis data untuk mencari hasil dari penelitian ini adalah dengan uji validitas dan uji realibilitas. Uji validitas digunakan untuk sah atau valid tidaknya suatu kuesioner. Suatu kuesioner dikatan valid jika pertanyaan dan kuesioner mampu untuk mengungkap sesuatu yang akandiukur oleh kuesioner tersebut (Ghozali, 2005:45). Validitas bertujuan mengukur apakah pertanyaan dalam kuesioner dibuat sudah betul-betul dapat mengukur apayang hendak diukur. Uji validitas menggunakan analisis korelasi Pearson untuk mengetahui keputusan valid tidaknya butir instrument. Syarat minimumuntuk dianggap memenuhi kriteria adalah apabila koefisien korelasi pada tingkat signifikan 5\% nilai nilai hitung $r$ hitung > rtabel, maka dapat disimpulkan bahwa butir instrument itu valid. 
Uji Realibilitas adalah alat untuk mengukur suatu kuesioner yang merupakan indikator dari suatu variable. Suatu kuesioner dikatakan reliableatau handal jika jawaban pertanyaan adalah konsisten atau stabil dari waktu ke waktu (Ghozali, 2005:41). Pengukuran reliabilitas dalam penelitian ini dilakukan dengan caraone shot atau pengukuran sekali saja. Disini pengukuran hanya sekali dan kemudian hasilnya dibandingkan dengan pertanyaan lain atau mengukur reliabilitas dengan uji static Cronbach Alpha (a). Menurut Gozali (2005:42) suatu variable dikatakan reliable jika nilai Cronbach Alpha (a)>0.6.

\section{HASIL DAN PEMBAHASAN}

\subsection{Deskripsi Data}

Pada penelitian ini akan membahas tentang produk paket wisata pedesaan (rural activitiy) pada D'Karang Homestay berdasarkan oleh persepsi wisatawan Eropa yang telah melakukan kegiatan tersebut selama menginap di D'karang homestay sebagai contoh sampel pada penelitian. Persepsi wisatawan akan dicantumkan dalam bentuk kuesioner, menurut hasil kuesioner diperoleh data berdasarkan faktor demografis (jenis kelamin, usia, pekerjaan) dan faktor psikografis (alasan berwisata, sumber informasi, frekuensi kunjungan ke Bali). Jumlah kuesioner yang telah disebarkan sebanyak 85 lembar sesuai hasil sampel responden berdasarkan rumus slovin, yang disebarkan mulai awal Agustus hingga akhir Oktober 2019.

\subsection{Pembahasan}

Teknik pengambilan sample pada penelitian ini adalah purposive sampling. Pada penelitian ini menggunakan teori bauran produk (product mix) dalam 3 tingkat produk biro perjalanan wisata menurut pendapat Kotler (Yoeti, $2006: 60$ ) yaitu: core product, tangible product, dan the augmented product. Penilaian responden akan dilakukan terhadap produk wisata pedesaan (rural activity) seperti: Short trekking, Farming program, village Tour, Cooking leason, waterfall trek, dan healing program / yoga yang ditawarkan oleh D'karang homestay. Berikut akan disajikan data yang telah diperoleh melalui penyebaran kuesioner dan wawancara.

\section{Karakteristik Responden:}

\section{Karakteristik Responden Berdasarkan Faktor Demografis}

Berdasarkan faktor demografis, karakteristik wisatawan dikelompokkan menjadi 4 variabel diantaranya adalah: kebangsaan, usia, jenis kelamin dan pekerjaan. Keempat variable tersebut akan dijabarkan sebagai berikut:

\section{1) Berdasarkan kebangsaan}

Berikut ini adalah wisatawan yang tertarik membeli dan melakukan kegiatan wisata pedesaan (rural activity) di D'Karang homestay adalah Polandia (Europe Timur) sebesar $49 \%$ hal ini disebabkan karena ketertarikan wisatawan Polandia terhadap budaya dan alam di Bali sangat besar karena sangat berbeda dengan alam dan budaya di negaranya, sedangkan negara Belanda yang memiliki ketertarikan membeli dan melakukan kegiatan rural activity sebesar 5\%, hal ini menurut wisatawan Belanda karena mereka memiliki hubungan dengan Indonesia sehingga ada beberapa kegiatan budaya yang hampir sama dengan Indonesia seperti : wisata kuliner, trekking dan cycling

2) Berdasarkan Usia

Usia merupakan salah satu factor yang menentukan seseorang untuk melakukan suatu aktivitas. Jumlah wisatawan yang membeli dan menikmati produk wisata pedesaan 
(rural activity) di D'karang homestay di dominasi oleh wisatawan yang berusia antara 31 sampai 40 tahun sebesar35\% karena pada usia ini menginginkan suatu suasana baru dan terlepas sejenak dari runtinitas yang menjenuhkan, dimana usia $31-40$ merupakan usia matang dalam jenjang karirnya sehingga pada usia ini membutuhkan suatu kegiatan atau aktivitas yang kembali ke suasana yang masih alami (back to nature). Sedangkan usia 17 - 20 merupakan usia yang memiliki minat lebih sedikit untuk membeli dan mengikuti kegiatan wisata pedesaan karena di usia ini mereka lebih memilih membeli dan mengikuti kegiatan yang bersifat tantangan (adventure).

3) Berdasarkan Jenis Kelamin Jumlah responden yang berjenis kelamin pria adalah 37 orang (44\%) dan wanita berjumlah 48 orang ( $56 \%$ ) dari keseluruhan responden yang berjumlah 85 orang.

4) Berdasarkan Pekerjaan

Pekerjaan juga merupakan salah satu faktor yang menentukan seseorang tertarik untuk mengikuti suatu kegiatan. Responden yang berasal dari wirausaha atau Entrepeneur yang memiliki ketertarikan untuk mencoba kegiatan wisata pedesaan / rural activity sebanyak 29 orang (34\%). Hal ini karena para wirausaha memiliki waktu yang luang untuk berlibur lebih banyak serta adanya tuntutan untuk menambah wawasan terhadap tren ekonomi ke depan atau juga sebagai ajang mencari inspirasi usaha sehingga mereka paling sering melakukan perjalanan wisata ke berbagai daerah dan mencoba berbagai kegiatan wisata baik yang bersifat petualangan maupun alam. Data responden bidang pekerjaan sebagai pegawai negeri sipil /PNS/Civil servant yang paling sedikit tertarik membeli dan melakukan kegiatan wisata pedesaan /rural activity sebesar $6 \%$, karena mereka memiliki waktu luang untuk berlibur sangat terbatas sehingga peluang mereka untuk menikmati kegiatan wisatapun menjadi terbatas.

Karakteristik Responden Berdasarkan Faktor Psikografis

1) Berdasarkan Psikografis

merupakan salah satu faktor yang mempengaruhi dan mendorong wisatawan untuk berkunjung ke Bali pada umumnya dan berkunjung ke D'karang homestay serta membeli dan menikmati kegiatan wisata pedesaan pada khususnya. Karakter wisatawan dikelompokkan menjadi tiga bagian yaitu: Frekuensi kunjungan ke Bali, Tujuan kunjungan dan sumber informasi tentang produk wisata pedesaan / rural activity di D'karang homestay.

2) Berdasarkan Frekuensi

Kunjungan ke Bali Karakteristik responden berdasarkan jumlah kunjungan ke Bali yaitu yang pertama kali kunjungan sebanyak 44 orang (52\%), untuk kedua kali kunjungan ada 25 orang (29\%), yang ketiga kali kunjungan ada 10 orang (12\%) dan yang berkunjung lebih dari empat kali sebanyak 7\%. Jadi karakteristik wisatawan berdasarkan frekuensi kunjungan ke Bali dan yang dominan membeli paket wisata pedesaan di D’karang homestay adalah wisatawan yang pertama kali mengunjungi Bali.

3) Berdasarkan Sumber Informasi

Berdasarkan kuesioner yang diolah dari 85 responden, jumlah responden mendapatkan informasi tentang paket wisata pedesaan (rural activity) di D'karang Homestay yaitu dari BPW atau travel agent sebanyak 35 orang (41\%), dari teman sebanyak 20 orang $(24 \%)$, dari kegiatan promosi yang dilakukan d'karang homestay sebanyak 11 orang (13\%) sedangkan dari keluarga sebanyak 10 orang (12\%), dari relasi sebanyak 7 orang $(8 \%)$ dan dari kolega hanya 2 orang (2\%). Dalam hal ini informasi dari kolega mendapat respon yang terendah dari responden.

4) Berdasarkan Alasan Berwisata 
Alasan responden berwisata yang paling mendominasi adalah berlibur atau leisure sebanyak 69 orang (81\%), jumlah responden yang melakukan bisnis sebanyak 6 orang (7\%), mengunjungi teman sebanyak 4 orang (5\%), kesehatan sebanyak 2 orang (2\%) sedangkan untuk alasan Pendidikan tidak ada (0\%) namun untuk alasan lainnya ada sebanyak 4 orang (5\%). Dalam hal ini alasan berwisata yang menjadi tujuan utama mereka untuk berkunjung dan melakukan aktivitas (rural activity) di D’karang Homestay

Uji Validitas

Menurut (Ghozali, 2005:45) uji validitas digunakan untuk mengukur sah atau valid tidaknya suatu kuesioner tersebut, kuesioner dikatakan valid jika kuisioner mampu untuk mengungkap sesuatu yang akan diukur menggunakan kuisioner tersebut. Uji validitas menggunakan analisis korelasi Pearson untuk mengetahui keputusan valid atau tidaknya butir instrument, syarat yang dianggap untuk memenuhi kriteria adalah apabila koefisien korelasi pada tingkat signifikan 5\% nilai r.hitung>r.tabel, maka dapat disimpulkan bahwa butir instrument itu valid.

Hasil Item Pertanyaan Uji Validitas Variabel Penelitian

\begin{tabular}{llll}
\hline Item Pertanyaan & r Hitung & r Tabel (5\%) & Ket. \\
\hline Core Product (Produk Inti) & & & \\
1.Guide & 0,707 & 0,361 & Valid \\
2.Atraksi Wisata & 0,926 & 0,361 & Valid \\
3.Daya Tarik wisata & 0,893 & 0,361 & Valid \\
4.Makanan & 0,755 & 0,361 & Valid \\
5.Transporasi & 0,671 & 0,361 & Valid \\
6.Program Tur & 0,883 & 0,361 & Valid \\
7.Akomodasi & 0,778 & 0,361 & Valid \\
Tangible Product & & & \\
1.Harga Promo & 0,744 & 0,361 & Valid \\
2.Fasilitas & 0,910 & 0,361 & Valid \\
3.FOC (free of charge) & 0,555 & 0,361 & Valid \\
4.Complimentari & 0,665 & 0,361 & Valid \\
5.Trend & 0,692 & 0,361 & Valid \\
6.Insurance & 0,671 & 0,361 & Valid \\
Augmented Product & & & \\
\hline
\end{tabular}

Uji Reliabilitas

Menurut (Ghozali, 2005: 41), Reabilitas merupakan alat untuk mengukur kuisioner yang merupakan indikator dari suatu variable. Suatu kuisioner di katakana reliable atau handal jika jawaban pertanyaan adalah konsisten atau stabil dari waktu ke waktu. Pengukuran reliabilitas dalam penelitian ini di lakukan dengan cara one shot atau pengukuran. 


\begin{tabular}{llll}
\hline No & Variabel & Koefisien Croncbach 's Alpha & Ke \\
\hline 1. & Core Product (Produk Inti) & 0,926 & Reliabel \\
2. & Tangibel Product & 0,905 & Reliabel \\
3. & Augmente d Product & 0,903 & Reliabel
\end{tabular}

Analisis Data

Pengukuran hanya sekali dan kemudian hasilnya dibandingkan dengan pertanyaan lain atau mengukur reliabilitas dengan uji statistic Croncbach alpha(a). Suatu variable dikatakan reliable jika nilai croncbach alpha (a)>0,6.

Hasil Perhitungan Core Product (Product Inti)

Dapat diketahui bahwa masing - masing tiga tingkat produk wisata memiliki nilai persepsi yang berbeda diantaranya seperti aspek Core Product (produk Inti) yang terdiri dari tujuh variable yaitu: dari segi kepemanduan memperoleh nilai sebanyak 4.45 yang berinterprestasi Sangat Baik, dari segi Atraksi wisata mendapat nilai 4.62 yang berintreprestasi Sangat baik, dari segi Daya Tarik wisata mendapat nilai 4.56 yang berinterprestasi Sangat baik, dari segi makanan (meals) memperoleh nilai sebesar 4.64 yang berinterprestasi Sangat baik, dari segi transportasi atau kendaraan mendapat nilai 4.43 yang berinterprestasi sangat baik, dari segi program tur memperoleh nilai 4.23 yang berinterprestasi sangat baik,dan dari degi akomodasi memperoleh nilai 4.15 yang interprestasinya terbilang baik. Jadi Core Product (produk inti) secara keseluruhan memperoleh nilai sebesar 4.44 yang diinterprestasikan Sangat Baik

Hasil Perhitungan Tangibel Product.

Aspek Tangibel Product terdiri dari enam variable yaitu dari segi harga promo yang mendapatkan nilai rata - rata sebanyak 4.10 yang berinterprestasi baik, dari segi Fasilitas memperoleh nilai sebesar 4.05 yang diinterprestasikan Baik, FOC (free of charge) mendapat nilai sebesar 3.83 yang berinterprestasi Baik, Complimentari memperoleh nilai 3.65 yang diinterprestasikan Baik, dari segi Trend memperoleh nilai sebesar 4.42 yang dinterprestasikan sangat baik, dari segi insurance/jaminan mendapat nilai sebesar 4.41 yang berinterprestasi sangat baik. Jadi Tangibel Product secara keseluruhan memperoleh nilai sebesar 4.07yang diinterprestasikan Baik.

\section{Hasil Perhitungan Augmented Product}

Sedangkan aspek Augmented product terdiri dari empat variable yaitu: dari segi kemudahan yang mendapat nilai sebesar 4.02 yang berinterprestasi Baik, dari segi promosi dan publisitas memperoleh nilai sebesar .23 yang berinterprestasi Baik, dari segi Hygine dan Sanitasi mendapat nilai 4.16 yang diinterprestaikan sangat baik, sedangkan layanan purna jual memperoleh nilai sebesar 3.71 yang diinterprestasinya tergolong baik. Jadi Augmented Product mendapat nilai sebesar 4.03 yang interprestasi Baik.

Hasil Perhitungan Total dari (Core Product, Tangibel Product, Augmented Product) Berdasarkan hasil tabulasi data di masing- masing variable yaitu core product( produk inti) yang memdapatkan nilai sebesar 4.44, Tangibel Product memperoleh nilai sebesar 4.07 dan Augmented Product mendapat nilai sebesar 4.03 Jadi dari masing masing nilai aspek tersebut dapat ditotalkan dan di rata- ratakan sehingga paket wisata pedesaan di D'karang homestay dikatagorikan dalam interprestasi Baik dengan nilai ratarata keseluruhan sebesar 4.18. 


\section{KESIMPULAN}

Persepsi wisatawan Eropa secara keseluruhan terhadap paket wisata pedesaan (rural Activity) di D'karang homestay dikatagorikan dalam interprestasi Baik dengan nilai rata-rata keseluruhan 4.18

1) Core Product (product inti) mendapatkan nilai rata - rata sebesar 4.44 dengan interprestasi sangat baik, yang meliputi tujuh variable yaitu: kepemanduan, atraksi wisata, daya Tarik wisata, makanan, transportasi / kendaraan, program turnya dan akomodasi.

2) Tangibel Product memperoleh nilai rata - rata sebesar 4.07 yang diinterprestasikan Baik, yang meliputi enam variable yaitu: harga promosi, fasilitas, FOC (free of charge), Complimentary, Trend, dan insurance /jaminan.

3) Augmented Product mendapatkan nilai rata-rata sebesar 4.03 diinterprestasikan Baik, yang meliputi empat variable yaitu: kemudahan, Promosi danpublikasi, Hygine dan sanitasi, dan layanan purna jual.

4) Wisatawan Eropa yang membeli dan menikmati paket wisata pedesaan di D'karang Homestay mayoritas wanita dan dengan umur $31-40$ tahun sebanyak 35\% sedangkan pekerjaan mayoritas wirausaha 34\%. Mereka melakukan perjalanan dengan alasan untuk berlibur atau rekreasi. Mayoritas wisatawan yang datang baru pertama kali dan banyak yang memperoleh informasi melalui Biro Perjalanan Wisata (BPW) yang bekerjasama dengan D'karang homestay.

Memperhatikan beberapa kesimpulan di atas maka dapat disarankan beberapa hal berikut:

1) Lebih memperhatikan dan mengemas atraksi wisata dan daya Tarik wisata yang dapat memenuhi kebutuhan dan keinginan wisatawan sehingga wisatawan merasa lebih puas sehingga dapat meningkatkan jumlah penjualan kedepannya.

2) Perlu dilakukan pengecekan dan perawatan yang lebih rutin agar kendaraan tidak bermasalah dan mengganggu pelaksaaan program tur paket wisata pedesaan.

3) Dalam aspek Augmented Product yaitu komponen fleksibilitas lebih di perhatikan agar wisatawan tidak mudah kecewa karena waktu diatur secara ketat dalam pelaksaan paket wisata pedesaan. Wisatawan belum puas dengan satu tempat atraksi wisata wisatawan sudah diminta untuk melanjtkan ke tempat yang lainnya.

4) Perlu memperhatikan kelengkapan fasilitas jika dilakukan pada musim hujan dan musim panas sehingga wisatawan tidak merasa kecewa.

\section{DAFTAR PUSTAKA}

Muljadi, J. (2009). Kepariwisataan dan Perjalanan. Jakarta: Raja Grafindo Persada

Dinas Pariwisata Propinsi Bali. 2019, The Number of Foreign Tourist Arrival to Bali by Month, Bali.

Dinas Pariwisata Kabupaten Bangli. (2019), Jumlah Kunjungan Wisatawan ke Kabupaten Bangli, Bali.

Hasan, A. (2015). Tourism Marketing. Yogyakarta:CAPS

Iskandar, (2008). Metodologi Penelitian Pendidikan dan Sosial (Kualitatif dan Kuantitatif). Jakarta: Gaung Persada Press.

Ismayanti. (2010). Pengantar Pariwisata. Jakarta: PT Gramedia Widiarsana Indonesia

Kotler, P. (2010). Manajemen Pemasaran. Edisi Tiga Belas Bahasa Indonesia. Jilid 1 dan 2. Jakarta: Erlangga.

Kusmayadi dan Sugiarto. (2000) Metode Penelitian dalam Bidang Kepariwisataan. Jakarta: Gramedia Pustaka Utama. 
Ni Putu Evi Wijayanti

Kusumanegara, I M. (2009). Persepsi Wisatwan Nusantara Terhadap Kondisi Kepariwisataan Bali. Jurnal Hospitality Management. Volume 3 No.1

Pitana, I G. (2005). Sosiologi Pariwisata. Yogyakarta: Andi.

Soekadijo, R.G. (2000). Anatomi Pariwisata, Memahami Pariwisata Sebagai Sistematic Linkage. Jakarta: Gramedia Pustaka Umum.

Sugiyono. (2008). Metode Penelitian Kuantitatif Kualitatif dan R\&D. Bandung: Alfabeta.

Suwantaro, G. (2004). Dasar-dasar Pariwisata. Yogyakarta: Andi 